\title{
ORIENTASI PASAR, STRATEGI DIFERENSIASI, DAN INOVASI PRODUK TERHADAP KEUNGGULAN BERSAING BERPENGARUH PADA INDUSTRI ENDEK
}

\author{
Nyoman Agus Surya Nugraha ${ }^{1}$ \\ I Putu Gde Sukaatmadja ${ }^{2}$
}

\author{
'*Fakultas Ekonomi dan Bisnis Universitas Udayana (Unud), Bali, Indonesia \\ email: agus.surya21 @gmail.com
}

\begin{abstract}
ABSTRAK
Penelitian ini dilakukan di Kabupaten Klungkung dengan 96 orang pemilik atau pengelola usaha kain endek sebagai sampel. Penentuan sampel dengan Sampling Jenuh. Pengumpulan data melalui kuesioner dan dianalisis dengan regresi linear berganda. Berdasarkan hasil analisis ditemukan bahwa Orientasi Pasar, Strategi Diferensiasi, dan Inovasi Produk secara simultan berpengaruh signifikan terhadap Keunggulan Bersaing. Terdapat pengaruh positif dan signifikan secara parsial antara Orientasi Pasar terhadap Keunggulan Bersaing Pada Industri Endek. Terdapat pengaruh positif dan signifikan secara parsial antara Strategi Diferensiasi terhadap Keunggulan Bersaing Pada Industri Endek. Terdapat pengaruh positif dan signifikan secara parsial antara Inovasi Produk terhadap Keunggulan Bersaing Pada Industri Endek. Upaya untuk meningkatkan keunggulan bersaing industri endek dapat dilakukan oleh pengusaha endek dengan cara mengumpulkan informasi tentang kebutuhan pelanggan, membuat desain kain endek yang memiliki perbedaan dan mudah dikenali dibandingkan dengan produk pesaing serta mencoba menjual produk di luar negeri.

Kata kunci: orientasi pasar, strategi diferensiasi, inovasi produk, keunggulan bersaing.
\end{abstract}

\begin{abstract}
This research conducted in Klungkung with 96 owners of the endek fabric business as samples. Determination of samples by Saturated Sampling. Data collection through questionnaires and analyzed with multiple linear regression. Based on the results, Market Orientation, Differentiation Strategy, and Product Innovation simultaneously have significant effect on Competitive Advantage. There is a partially positive and significant influence between Market Orientation and Competitive Advantage in the Endek Industry. There is a positive and partially significant influence between the Differentiation Strategy on Competitive Advantage in the Endek Industry. There is a partially positive and significant influence between Product Innovation on Competitive Advantage in the Endek Industry. Efforts to increase the competitive advantage of the endek industry can be carried out by endek entrepreneurs by collecting information about customer needs, making endek fabric designs that are different and easily recognizable compared to competitors' products and trying to sell products abroad.

Keywords: market orientation, differentiation strategy, product innovation, competitive advantage.
\end{abstract}




\section{PENDAHULUAN}

Salah satu penggerak ekonomi di Indonesia adalah Usaha Mikro, Kecil, dan Menengah (UMKM). UMKM adalah suatu unit usaha kecil yang mampu berperan sebagai alternatif kegiatan usaha produksi barang dan jasa, meningkatkan devisa negara, dan membantu penyerapan tenaga kerja. UMKM memainkan peran penting dalam pembangunan ekonomi dan sosial suatu negara. Peran UMKM tercermin dalam penciptaan lapangan kerja dan pendapatan, serta peningkatan neraca perdagangan dan merupakan mekanisme utama dalam merevitalisasi dan meningkatkan kemajuan ekonomi nasional. Selain itu, UMKM adalah titik awal pengembangan ke dalam suatu industri, karena sebagian besar perusahaan besar saat ini dikembangkan dari UMKM (Varadarajan, 2017).

Saat ini, UMKM telah menjadi penghubung antara ekonomi makro dan ekonomi mikro. Ekonomi suatu negara tumbuh dengan mantap dan berkelanjutan ketika UMKM terus berkembang. Pemerintah di banyak negara memiliki kebijakan nasional untuk mendukung dan mempromosikan UMKM untuk meningkatkan daya saing negara termasuk Indonesia. Namun saat ini jumlah pelaku industri UMKM di Indonesia masih dapat dikatakan relatif kecil dibandingkan dengan negara maju atau negara tetangga di ASEAN. Data pada tahun 2016 dari Global Entrepreneurship Monitor (GEM) menunjukkan bahwa Indonesia baru mempunyai sekitar 1,65 persen pelaku wirausaha dari total jumlah penduduk 250 juta jiwa. Angka tersebut menunjukkan bahwa jumlah yang dimiliki Indonesia masih tertinggal dibandingkan tiga negara di Asia Tenggara yakni Singapura sebesar 7 persen, Malaysia 5 persen, dan Thailand 3 persen dari total jumlah penduduk masing-masing (Doyle \& Armenakyan, 2016).

Menurut Gault (2018) UMKM memiliki kelebihan yaitu tidak mudah goncang, karena bahan baku dan sumber daya untuk produksi lebih banyak dapat diperoleh atau diproduksi dalam negeri sehingga tidak terpengaruh terhadap fluktuasi bahan baku impor. Bahkan bila harga bahan baku mahal akibat tingginya nilai mata uang asing, perusahaan kecil yang menggunakan bahan baku lokal dapat berpeluang memproduksi barang - barang untuk keperluan ekspor. Namun, di sisi lain daya saing yang rendah dari UMKM menyebabkan kelompok ini mengalami kesulitan dalam meningkatkan outputnya (Love \& Mcgee, 2015). Menurut Almaidah \& Wagiyem (2016) keterbatasan yang sering dihadapi UMKM sehingga daya saingnya rendah seperti: (1) kurang mampu beradaptasi dengan lingkungan bisnis secara keseluruhan, (2) terbatasnya akses pada sumber pembiayaan, (3) lemah pada akses pasar, (4) produktivitas yang tidak optimal, dan (5) kurang efisien.

Provinsi Bali berdasarkan data yang diperoleh dari Dinas Koperasi dan UKM Provinsi Bali per Maret 2018 merupakan provinsi di Indonesia yang warganya banyak berkecimpung dalam dunia bisnis UMKM. Data yang diperoleh dari Dinas Koperasi dan UKM Provinsi Bali per Maret 2018 terdapat 313.822 unit industri UMKM dengan rasio jumlah wirausaha di Bali terhadap jumlah penduduk adalah sebanyak 7,39 persen. Ada beragam industri yang berkembang di Bali seperti industri makanan dan minuman, obat-obatan tradisional, perkebunan, pertanian, logam, kelautan, kerajaninan dan tekstil. Salah satu industri yang berkembang dan patut dilestarikan yang ada di Bali adalah Industri kerajinan 
tenun ikat yang memproduksi kain endek. Kain endek merupakan kain tenun ikat khas Bali yang dibuat dengan cara menenun secara tradisional menggunakan Alat Tenun Bukan Mesin (ATBM).

Kain endek Bali memiliki beragam warna yang menarik serta motif yang unik seperti flora, fauna, dan motif tokoh pewayangan. Selain itu, kain endek ini menggunakan benang dengan kualitas yang bagus dan pewarna alami. Hampir semua proses produksi dilakukan secara manual dan memerlukan waktu yang relatif lama sehingga kain endek merupakan kerajinan tangan yang memiliki keunikan berbasis budaya lokal. Meskipun demikian, potensi yang dimiliki oleh industri kain endek tidak diimbangi dengan kemampuan untuk bersaing. Menurut Dinas Perindustrian dan Perdagangan Provinsi Bali dewasa ini industri kain endek di Kabupaten Klungkung yang merupakan pusat produksi kain endek mengalami persaingan ketat dikarenakan munculnya pesaing, baik itu dari Bali sendiri maupun dari luar Bali. Munculnya beberapa pesaing usaha tersebut yang mampu memproduksi kain endek dengan harga jauh lebih murah dengan menggunakan alat tenun mesin namun memiliki standar kualitas yang lebih rendah. Jika hal ini berlangsung terus-menerus maka industri kain endek tradisional akan sulit berkembang dan tergeser. Berdasarkan data yang diperoleh dari Dinas Perindustrian dan Tenaga Kerja Kabupaten Klungkung pada tahun 2018 terdapat 96 industri endek yang masih bertahan di Kabupaten Klungkung.

Pelaku UMKM seperti industri kain endek harus secara tanggap mencermati berbagai permasalahan dan persaingan yang semakin ketat. Lingkungan persaingan, selera pelanggan yang dinamis, dan fluktuatif penjualan menjadikan para pelaku UMKM agar sensitif dengan perubahan, sehingga UMKM harus membangun keunggulan bersaing agar memiliki keunggulan dalam persaingan dan berkelanjutan di pasar. Menurut Dalimunthe (2017), faktor -faktor penentu keunggulan bersaing suatu perusahaan yaitu: (1) Faktor-faktor kondisi antara lain, kualitas, keterampilan, tenaga kerja, aksesibilitas, ketersediaan sumber daya pengetahuan, jumlah dan biaya dari sumber modal dalam struktur industri keuangan, dan ketersediaan serta kualitas infrastruktur fisik; (2) Kondisi permintaan antara lain, komposisi permintaan pasar, ukuran dan pertumbuhan pasar; (3) Industri yang terkait dan industri penunjang antara lain, keberadaan dan kualitas industri penunjang dan hubungan antara industri lokal dalam koordinasi dan pembagian aktivitas dalam rantai nilai; dan (4) Faktor eksternal antara lain penemuan baru dan faktor dari pemerintah.

Menurut Hosseini et al. (2018) suatu perusahaan dikatakan memiliki keunggulan bersaing ketika tingkat keuntungannya lebih tinggi dari tingkat ratarata industri terkait, dan dikatakan telah mempertahankan keunggulan bersaing ketika mempertahankan tingkat laba tinggi selama beberapa tahun. Tujuan utama sebuah organisasi dalam menciptakan keunggulan bersaing, berdasarkan sumber daya dan kemampuannya, adalah untuk mendapatkan daya saing dan mencapai posisi berbeda terkait kinerja di pasar bisnis. Kunci untuk mencapai daya saing adalah keberlanjutan keunggulan bersaing berdasarkan identifikasi dan persepsi permintaan pelanggan, konsentrasi pada pelanggan, dan peningkatan proses dari perspektif pelanggan. 
Menurut Gunarathne (2015) keunggulan bersaing mempunyai dua pemahaman definisi yang berbeda tetapi saling berhubungan. Pemahanan pertama berpandangan pada basis sumber daya dan pemahanan kedua berpandangan kekuatan bersaing. Pengertian pertama, menekankan pada keunggulan atau superior dalam hal sumber daya dan keahlian yang dimiliki perusahaan. Perusahaan yang memiliki kompetensi dalam bidang pemasaran, manufacturing, dan inovasi dapat menjadikannya sebagai sumber-sumber untuk mencapai keunggulan bersaing. Melalui ketiga bidang kompetensi tersebut, perusahaan dapat mengembangkan strategi sehingga dapat menghasilkan produk diterima dipasaran. Pengertian kedua, menekankan pada keunggulan dalam pencapaian kinerja selama ini (Julian et al., 2015).

Keunggulan bersaing pada dasarnya tumbuh dari nilai-nilai atau manfaat yang diciptakan oleh perusahaan bagi para pelanggan. Pelanggan umumnya lebih memilih membeli produk yang memiliki nilai lebih dari yang diinginkan atau diharapkannya. Namun demikian nilai tersebut juga akan dibandingkan dengan harga yang ditawarkan. Pembelian produk akan terjadi jika pelanggan menganggap harga produk sesuai dengan nilai yang ditawarkannya. Beberapa indikator yang digunakan untuk mengukur keunggulan bersaing adalah keunikan, jarang dijumpai, tidak mudah ditiru, tidak mudah diganti, dan harga bersaing. Berdasarkan hasil tinjauan dari berbagai literatur diperoleh bahwa keunggulan bersaing paling tidak dipengaruhi oleh tiga faktor penting, yaitu orientasi pasar, strategi diferensiasi dan inovasi produk (Sigalas \& Pekka Economou, 2017).

Implementasi orientasi pasar akan membawa pengaruh untuk meningkatkan keunggulan bersaing, hal ini sesuai dengan penelitian oleh Jayaningrum \& Sanawiri (2018) yang menunjukkan bahwa orientasi pasar berpengaruh secara positif dan signifikan terhadap keunggulan bersaing. Jayaningrum \& Sanawiri (2018) berpendapat bahwa perusahaan yang menerapkan orientasi pasar memiliki kelebihan dalam hal pengetahuan pelanggan dan kelebihan ini dapat dijadikan sebagai sumber untuk menciptakan produk yang sesuai dengan keinginan dan kebutuhan pelanggan.

Hasil yang berbeda mengenai pengaruh orientasi pasar terhadap keunggulan bersaing ditemukan pada penelitian yang dilakukan oleh Zainul et al. (2016) yang melakukan penelitian pada UKM Sasirangan yang ada di Kalimantan Selatan. Hasil penelitiannya menunjukkan bahwa orientasi pasar memiliki pengaruh langsung yang tidak signifikan terhadap keunggulan bersaing. Hasil ini menggambarkan bahwa orientasi pasar melalui indikator orientasi pelanggan, orientasi pesaing, dan koordinasi fungsi tidak memberikan kontribusi yang cukup baik dalam menciptakan keunggulan bersaing. Kondisi demikian, terjadi karena pengetahuan tentang orientasi pasar, terutama pengetahuan tentang orientasi pesaing, relatif terbatas bagi pemilik UKM Sasirangan.

Selain orientasi pasar, inovasi produk juga dapat dijadikan sebagai salah satu strategi dalam mencapai keunggulan bersaing suatu perusahaan sesuai dengan hasil penelitian oleh Supriyanto et al. (2017). Menurut hasil penelitianSupriyanto et al. (2017) pada UMKM Kopiah Haji di Kabupaten Hulu Sungai Tengah menemukan bahwa terdapat hubungan yang positif dan signifikan antara inovasi produk dan keunggulan bersaing. Adanya produk yang inovatif maka pastinya 
akan menciptakan sekaligus meningkatkan keunggulan bersaing produk. Inovasi produk merupakan kunci utama keberhasilan produk untuk dapat diterima oleh konsumen dalam memenangkan persaingan, karena saat ini konsumen sangat kritis ketika menentukan pilihannya akan suatu produk, mereka tidak hanya menginginkan produk yang murah dan berkualitas, tetapi juga adanya inovasi dari produk tersebut.

Menurut Sukarmen et al. (2015), Inovasi produk merupakan sesuatu yang dapat dilihat sebagai kemajuan fungsional produk yang dapat membawa produk selangkah lebih maju dibandingkan dengan produk pesaingnya. Menurut Nasir (2019) bagi perusahaan kecil dan menengah inovasi produk merupakan hal yang penting bagi kelangsungan bisnis secara berkelanjutan dan upaya untuk melakukan inovasi produk merupakan fungsi penting dari pihak manajemen suatu perusahaan karena inovasi produk dapat menentukan suatu kinerja pemasaran yang berkualitas. Pattipeilohy (2018) berpendapat bahwa untuk memenangkan persaingan perusahaan atau UKM harus melakukan inovasi. Inovasi akan meningkatkan nilai tambah suatu produk, inovasi akan menciptakan suatu produk baru yang dapat memberikan solusi yang lebih baik bagi pemecahan masalah yang dihadapi konsumen.

Strategi diferensiasi adalah strategi penting lain yang berpengaruh terhadap keunggulan bersaing sesuai dengan hasil penelitian Setyowati \& Fadah (2018) dan Satyarini (2016). Menurut hasil pembahasan oleh Setyowati \& Fadah (2018) mengatakan bahwa strategi diferensiasi berpengaruh pada keunggulan bersaing, karena perusahaan dapat menciptakan perbedaan yang tidak dimiliki oleh perusahaan yang lain. Strategi diferensiasi menurut Satyarini (2016) adalah strategi perusahaan untuk menciptakan suatu produk yang unik, yang berbeda dengan pesaing. Keunikan inilah yang merupakan superior value bagi konsumennya. Superior value tersebut haruslah dilihat dari sisi konsumen dan bukan dilihat dari sisi produsen. Beberapa kesalahan yang seringkali dibuat oleh para produsen adalah seringkali value yang ditawarkan oleh produsen bukanlah value yang dicari konsumennya atau value yang ditawarkan tidak bersifat unik, karena hampir semua produk dari pesaing menawarkan value yang sama. Perusahaan yang memiliki superior value menerapkan harga yang berbeda dengan pesaingnya tanpa harus khawatir kehilangan pelanggan hanya karena pesaing menetapkan harga yang lebih rendah. Diferensiasi secara signifikan merupakan faktor penting yang memungkinkan perusahaan memahami pasar dan mengembangkan strategi produk dan jasa untuk memenuhi kebutuhan pelanggan dan kebutuhan pasar (Zaricha, 2018).

Diferensiasi produk menjadi aspek penting dalam suatu organisasi yang mempengaruhi target konsumen menjadi pelanggan setia perusahaan dibandingkan dengan pesaing lainnya. Hardjono \& Utari (2016) menyatakan bahwa diferensiasi produk yang berhasil adalah diferensiasi yang mampu mengalihkan basis persaingan ke faktor lain, seperti karakteristik produk, strategi distribusi atau variabel-variabel promotif lainnya. Tanpa diferensiasi produk, produk perusahaan hanya akan menjadi komoditi. Artinya, produk tersebut tidak berbeda jauh dengan produk yang lain, alias produk rata-rata. Umumnya diferensiasi produk akan mengakibatkan konsumen merasa puas terhadap produk 
yang ditawarkan, kemudian diharapkan konsumen tersebut akan melakukan pembelian lagi, namun jika konsumen merasa tidak puas, kosumen tersebut akan menghentikan pembelian.

Research gap dalam penelitian ini adalah pengaruh orientasi pasar terhadap keunggulan bersaing. Seperti yang telah dikemukakan di atas bahwa terdapat perbedaan hasil yang ditemukan dalam penelitian Jayaningrum \& Sanawiri (2018) yang menemukan hasil orientasi pasar berpengaruh secara positif dan signifikan terhadap keunggulan bersaing, sedangkan penelitian oleh Zainul et al. (2016) menemukan hasil orientasi pasar memiliki pengaruh langsung yang tidak signifikan terhadap keunggulan bersaing, Jika mempertimbangkan hasil penelitian Zainul et al. (2016) maka diduga adanya pengaruh positif dan signifikan orintasi pasar pada industri endek di Kabupaten Klungkung yang juga merupakan UKM akan dipengaruhi oleh pengetahuan pengusaha industri endek perihal orientasi pasar. Oleh karena hal ini, penelitian mengenai pengaruh orientasi pasar terhadap keunggulan bersaing pada industri endek di Klungkung perlu dilakukan untuk mengkomfirmasi penelitian sebelumnya. Dua faktor lainnya yaitu strategi diferiensiasi dan inovasi produk juga perlu diteliti karena secara konsisten pada penelitian sebelumnya menunjukkan hasil positif dan signifikan terhadap keunggulan bersaing, hal ini penting untuk mengetahui apakah dua faktor ini sudah diperhatikan oleh pengusaha yang bergerak di bidang industri endek di kabupaten Klungkung dan pengaruhnya terhadap keunggulan bersaing.

Berdasarkan uraian latar belakang, maka tujuan dalam penelitian ini adalah: 1) untuk mengetahui signifikansi pengaruh orientasi pasar terhadap keunggulan bersaing, 2) untuk mengetahui signifikansi pengaruh strategi difrensiasi terhadap keunggulan bersaing. 3) Untuk mengetahui signifikansi pengaruh inovasi produk terhadap keunggulan bersaing.

Hubungan yang terjadi antara orientasi pasar, strategi diferensiasi dan inovasi produk dan keunggulan bersaing yang akan digunakan dalam penelitian ini dapat digambarkan dengan kerangka konseptual berikut:

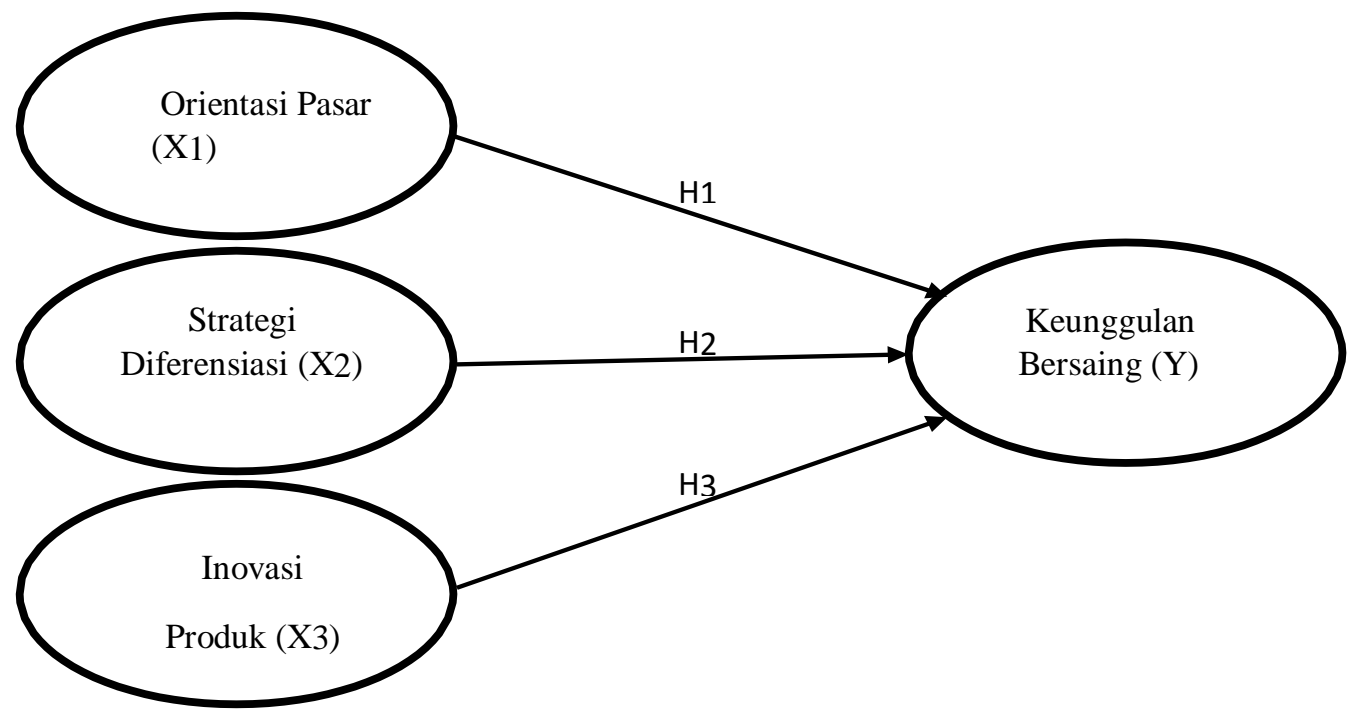

Gambar 1. Kerangka Konseptual 
Menurut hasil penelitian Sachitra (2016), orientasi pasar mempromosikan aktivitas pemrosesan informasi pasar organisasi serta cara penggunaannya dalam strategi perusahaan. Perusahaan yang berorientasi pasar peduli dengan pelanggan dan pesaing. Lebih jauh, orientasi pasar terletak pada sejauh mana perusahaan memperoleh dan bereaksi terhadap umpan balik dari pelanggan dan pesaing. Misalnya, perusahaan yang berorientasi pasar terus mengumpulkan informasi tentang kebutuhan pelanggan dan kemampuan target pesaing. Perusahaan selanjutnya menggunakan informasi tersebut untuk terus menciptakan nilai pelanggan yang unggul. Oleh karena itu, orientasi pasar berkaitan dengan proses dan rutinitas tertentu yang menciptakan nilai superior bagi pelanggan. Ini juga membantu perusahaan dalam mendapatkan keunggulan bersaing yang berkelanjutan.

Hasil penelitian Dalimunthe (2017) menunjukkan bahwa orientasi pasar berpengaruh secara positif terhadap keunggulan bersaing kelompok usaha kuliner di Kelurahan Suka Maju. Orientasi pasar sangat efektif dalam mendapatkan dan mempertahankan keunggulan bersaing, yang dimulai dengan perencanaan dan koordinasi dengan semua bagian yang ada dalam perusahaan untuk memuaskan kebutuhan dan keinginan konsumen. Oleh karena itu, orientasi pasar harus menekankan pentingnya analisis kebutuhan dan keinginan target pasar secara lebih efisien dan efektif dibandingkan dengan pesaingnya dalam usaha untuk mencapai keunggulan bersaing. Penekanan orientasi pasar terhadap daya saing berdasarkan pada pengidentifikasian kebutuhan pelanggan sehingga setiap perusahaan dituntut untuk dapat menjawab kebutuhan yang diinginkan konsumen baik itu melalui penciptaan produk yang baru atau pengembangan dari produk yang sudah ada, agar dapat menciptakan superior value bagi konsumennya secara berkelanjutan dan dapat menjadi modal utama bagi perusahaan untuk dapat memenangkan persaingan.

Penelitian yang dilakukan oleh Jayaningrum \& Sanawiri (2018) mengenai pengaruh orientasi pasar tehadap keunggulan bersaing kuliner kafe di Kota Malang menunjukkan bahwa orientasi pasar berpengaruh secara positif dan signifikan terhadap keunggulan bersaing. Perusahaan yang menerapkan orientasi pasar memiliki kelebihan dalam hal pengetahuan pelanggan dan kelebihan ini dapat dijadikan sebagai sumber untuk menciptakan produk yang sesuai dengan keinginan dan kebutuhan pelanggan.

Penelitian yang dilakukan oleh Herman et al. (2018) menunjukkan bahwa orientasi pasar memiliki pengaruh yang positif terhadap keunggulan bersaing. Orientasi pasar memiliki tiga komponen: orientasi pelanggan, orientasi pesaing dan koordinasi antar fungsi. Orientasi pelanggan dan orientasi pesaing adalah kegiatan yang selalu terlibat dalam memperoleh informasi tentang konsumen dan pesaing di pasar sasaran, sementara koordinasi antar fungsi didasarkan pada informasi pelanggan dan pesaing dan terdiri dari usaha bisnis yang terkoordinasi. Jika ketiga komponen ini diimplementasikan oleh perusahaan, maka perusahaan akan dapat menerapkan orientasi pasar dalam mencari berbagai informasi pasar sehingga dapat menjadi dasar bagi perusahaan untuk menentukan langkah selanjutnya.

Sebuah bisnis yang menerapkan orientasi pasar tentu akan mengetahui informasi tentang pembeli sehingga perusahaan dapat dengan mudah mendapatkan 
pelanggan atau pelanggan. Penerapan orientasi pasar ini juga akan berorientasi pada pesaing, dimana kegiatan ini merupakan kegiatan untuk mengetahui kelemahan atau kekurangan produk yang dihasilkan oleh pesaing, sehingga perusahaan dapat menghasilkan produk yang lebih baik daripada pesaing. Dengan penerapan orientasi pasar ini, maka akan meningkatkan keunggulan bersaing suatu perusahaan. Berdasarkan penelitian tersebut maka dapat ditarik hipotesis.

$\mathrm{H}_{1}$ : Orientasi pasar berpengaruh positif dan signifikan terhadap keunggulan bersaing

Penelitian yang dilakukan oleh Hakim \& Faizah (2018) diferensiasi mempunyai pengaruh positif signifikan terhadap keunggulan bersaing. Strategi diferensiasi didasarkan pada pelayanan atau bentuk dengan sesuatu yang berbeda atau unik, yang membuat produk atau jasa perusahaan berbeda dari para pesaingnya. Menurut hasil pembahasan oleh Setyowati \& Fadah (2018) mengatakan "strategi diferensiasi berpengaruh pada keunggulan bersaing, karena jika suatu perusahaan bisa menciptakan perbedaan yang tidak dimiliki oleh perusahaan yang lain, maka perusahaan tersebut dapat menghasilkan keunggulan."

Penelitian yang dilakukan oleh Job \& Nyongesa (2016) menunjukkan bahwa "strategi difrensiasi produk berpengaruh secara positif terhadap keunggulan bersaing." Diferensiasi produk mencerminkan tekanan kompetitif yang diberikan oleh produsen dan pelanggan. Secara tidak langsung, meningkatkan fokus pelanggan dapat membantu mengidentifikasi kesenjangan pasar dan mengungkapkan peluang pasar baru. Berdasarkan penelitian tersebut maka dapat ditarik hipoptesis.

$\mathrm{H}_{2}$ : Strategi diferensiasi berpengaruh positif dan signifikan terhadap keunggulan bersaing

Penelitian Supriyanto et al. (2017) pada UMKM Kopiah Haji di Kabupaten Hulu Sungai Tengah menemukan bahwa terdapat hubungan yang positif dan signifikan antara inovasi produk dan keunggulan bersaing. Adanya produk yang inovatif maka pastinya akan menciptakan sekaligus meningkatkan keunggulan bersaing produk. Inovasi produk merupakan kunci utama keberhasilan produk untuk dapat diterima oleh konsumen dalam memenangkan persaingan, karena saat ini konsumen sangat kritis ketika menentukan pilihannya akan suatu produk, mereka tidak hanya menginginkan produk yang murah dan berkualitas, tetapi juga adanya inovasi dari produk tersebut.

Hasil penelitian oleh Dalimunthe (2017) menunjukkan bahwa inovasi produk memiliki pengaruh positif terhadap keunggulan bersaing. Oleh karena itu, perusahaan diharapkan membentuk inovasi baru dalam menghadapi baik pesaing, pelanggan dan pasar yang ada. Adanya kesamaan tampilan produk sejenis maupun sistem perusahaan sejenis dari pesaing merupakan faktor pendorong terjadinya inovasi, biasanya produk pesaing itu muncul tanpa mengalami perubahan yang berarti bahkan cenderung statis. Keadaan tersebut dapat menjadi hal yang menguntungkan, karena persaingan yang timbul dengan munculnya produk pesaing dapat diatasi dengan melakukan inovasi produk. Selain inovasi produk, sistem dalam perusahaan juga perlu adanya inovasi. Inovasi merupakan sesuatu yang dapat dilihat sebagai kemajuan fungsional yang dapat membawanya selangkah lebih maju 
dibandingkan pesaing, apabila memiliki suatu kelebihan yang dipandang sebagai nilai tambah bagi konsumen

Penelitian Kurniasari \& Utama (2018) pada UKM kerajinan enceng gondok menunjukkan bahwa inovasi produk secara individual berpengaruh positif dan signifikan terhadap keunggulan bersaing. Perusahaan dapat melakukan berbagai inovasi dengan membuat berbagai macam desain produk, dan menambah nilai guna suatu barang. Inovasi sangat penting bagi sebuah perusahaan. Inovasi produk juga merupakan salah satu dampak dari perubahan teknologi yang cepat. Kemajuan teknologi yang cepat dan tingginya tingkat persaingan menuntut setiap perusahaan untuk terus menerus melakukan inovasi produk yang pada akhirnya akan meningkatkan keunggulan bersaing pada perusahaan tersebut. Perusahaan menciptakan inovasi produk dengan berbagai macam desain produk, sehingga meningkatkan alternatif pilihan, meningkatkan manfaat atau nilai yang diterima oleh pelanggan, sehingga inovasi produk adalah salah satu cara perusahaan dalam mempertahankan keunggulan bersaing. Berdasarkan penelitian tersebut maka dapat ditarik hipotesis.

$\mathrm{H}_{3}$ : Inovasi produk berpengaruh positif dan signifikan terhadap keunggulan bersaing.

\section{METODE PENELITIAN}

Penelitian ini menggunakan pendekatan kuantitatif dan asosiatif. Penelitian ini dilakukan di Kabupaten Klungkung. Lokasi ini dipilih karena terdapat 96 pengusaha endek tradisonal di Kabupaten Klungkung. Subjek dalam penelitian ini adalah pemilik atau pengelola industri endek di Kabupaten Klungkung. Objek dalam penelitian ini adalah tentang keunggulan bersaing industri endek yang ditentukan oleh orientasi pasar, strategi diferensiasi, dan inovasi produk. Variabel bebas dalam penelitian ini adalah orientasi pasar (X1), strategi diferensiasi (X2), dan inovasi produk (X3). Variabel terikat penelitian ini adalah keunggulan bersaing (Y).

Jenis data yang digunakan dalam penelitian ini adalah data kuantitatif dan data kualitatif. Data kuantitatif yang digunakan adalah hasil jawaban angket yang dikerjakan responden berupa poin skala likert hasil pengukuran variabel yang diteliti. Data kualitatif berupa informasi mengenai nama responden, nama perusahaan serta alamat perusahaan responden. Data primer yang digunakan pada penelitian ini adalah para responden yang menjadi anggota sampel yang langsung memberikan tanggapan terhadap variabel-variabel penelitian yang akan diuji. Data sekunder dalam penelitian ini adalah berupa data nama pengusaha industri endek di Kabupaten Klungkung beserta alamat tempat usaha Tahun 2018 yang diperoleh dari Dinas Perindustrian dan Tenaga Kerja di Kabupaten Klungkung.

Mengingat penelitian ini membahas variabel orientasi pasar, strategi diferensiasi, inovasi, dan keunggulan bersaing, maka populasi sasaran penelitian ini adalah seluruh pengusaha yang bergerak di bidang industri kain endek di Kabupaten Klungkung yang terdaftar pada Dinas Perindustrian dan Tenaga Kerja Kabupaten Klungkung Tahun 2018 Kabupaten Klungkung. Banyaknya pengusaha endek berdasarkan data tersebut adalah 96 pengusaha. Pada penelitian ini ukuran sampel 
yang digunakan adalah sebesar 96 responden yang merupakan jumlah seluruh pengusaha industri kain endek yang berkembang di Kabupaten Klungkung berdasarkan data resmi yang diproleh secara langsung di Dinas Perindustrian dan Tenaga Kerja Tahun 2018. Responden pada penelitian ini adalah pemilik atau pengelola usaha kain endek yang berada di Kabupaten Klungkung.

Penentuan sampel dalam penelitian ini dilakukan dengan jenis Non Probability Sampling, yaitu teknik sampling saat semua unsur atau elemen populasi mempunyai kesempatan sama untuk bisa dipilih menjadi sampel. Teknik Non Probability Sampling yang dipilih yaitu dengan sampling jenuh (sensus) yaitu metode penarikan sampel bila semua anggota populasi dijadikan sebagai sampel. Metode pengumpulan data dalam penenelitian ini menggunakan metode survey yaitu teknik wawancara menggunakan kuesioner.

\section{HASIL DAN PEMBAHASAN}

Data karakteristik responden adalah data responden yang dikumpulkan untuk mengetahui profil responden penelitian. Berdasarkan hasil penelitian yang dilakukan terhadap pengerajin Industri Endek di Kabupaten Klungkung dapat diketahui karakteristik respondennya meliputi jenis kelamin, usia dan pendidikan terakhir

Jumlah pengerajin Pada Industri Endek di Kabupaten Klungkung yang di jadikan sampel sebanyak 96 orang. Jika di lihat dari jenis kelamin, jenis kelamin perempuan mendominasi dalam penelitian ini dengan persentase sebesar 59,38 persen. Jika di lihat dari usia, yang memiliki usia 42-50 tahun mendominasi dengan presentase sebesar 46,88 persen. Jika di lihat dari lama menjadi nasabah responden yang memiliki yang pendidikan terakhir selama SMA yang mendominasi dengan persentase sebesar 47,92 persen.

Tabel 1.

Hasil Uji Reliabilitas

\begin{tabular}{lc}
\hline \multicolumn{1}{c}{ Variabel } & Cronbach's Alpha \\
\hline Orientasi Pasar (X1) & 0,920 \\
Strategi Diferensiasi (X2) & 0,980 \\
Inovasi Produk (X3) & 0,943 \\
Keunggulan Bersaing (Y) & 0,966 \\
\hline
\end{tabular}

Sumber: Data primer (data diolah), 2020

Tabel 1. menunjukkan masing-masing nilai Cronbach's Alpha pada tiap instrumen tersebut lebih besar dari 0,6 (Cronbach's Alpha > 0,6). Hal tersebut menunjukkan bahwa semua instrumen reliabel sehingga dapat digunakan untuk melakukan penelitian.

Tabel 2. menunjukkan bahwa seluruh koefisien korelasi dari indikator variabel yang diuji nilainya lebih besar dari $0,30(\mathrm{r}>0,3)$. Hasil tersebut menunjukkan bahwa seluruh indikator yang terdapat pada penelitian ini terbukti valid. 
Tabel 2.

Hasil Uji Validitas

\begin{tabular}{cccc}
\hline No & Variabel & $\begin{array}{c}\text { Item } \\
\text { Pernyatan }\end{array}$ & Korelasi Item Total \\
\hline 1 & Orientasi Pasar & X1.1 & 0,860 \\
& & X1.2 & 0,917 \\
& & X1.3 & 0,903 \\
& & X1.4 & 0,924 \\
& Strategi Diferensiasi & X2.1 & 0,977 \\
& & X2.2 & 0,967 \\
& & X2.3 & 0,971 \\
& & X2.4 & 0,979 \\
& & X2.5 & 0,918 \\
& Inovasi Produk & X3.1 & 0,908 \\
& & X3.2 & 0,912 \\
& & X3.3 & 0,911 \\
4 & X3.4 & 0,894 \\
& & X3.5 & 0,896 \\
& & Y1.1 & 0,897 \\
& & Y1.2 & 0,952 \\
& & Y1.3 & 0,966 \\
& & Y1.4 & 0,946 \\
& & Y1.5 & 0,949 \\
\hline
\end{tabular}

Sumber: Data primer (data diolah), 2020

Variabel Keunggulan Bersaing pada penelitian ini merupakan variabel terikat. Variabel Keunggulan Bersaing yang disimbolkan dengan Y serta diukur dengan menggunakan lima pernyataan yang ditanggapi menggunakan lima poin Skala Likert. Berdasarkan Tabel 3. secara umum diperoleh hasil bahwa rata-rata skor variabel Keunggulan Bersaing berada pada kategori baik, Hal ini berarti bahwa sebagian besar responden memiliki keunggulan bersaing yang mampu membuat mereka bertahan di industri endek.

Variabel Keunggulan Bersaing yang memiliki rata-rata terendah adalah pernyataan "Harga produk yang saya tawarkan mampu bersaing dengan produk endek tradisional lainnya", diperoleh nilai rata-rata sebesar 3,36 yang masuk kriteria cukup baik, tetapi memiliki nilai rata-rata yang rendah dibandingkan dengan pernyataan yang lainnya. Ini berarti secara umum harga produk yang responden tawarkan belum mampu bersaing dengan produk endek tradisional lainnya Variabel Keunggulan Bersaing yang memiliki rata-rata tertinggi adalah pernyataan "Produk yang saya jual berkualitas tinggi", diperoleh nilai rata-rata sebesar 3,47 yang masuk kriteria baik, ini berarti secara umum responden yakin produk yang mereka jual berkualitas tinggi.

Variabel Orientasi Pasar pada Tabel 4. merupakan variabel bebas. Variabel Orientasi Pasar yang disimbolkan dengan X1 serta diukur dengan menggunakan empat pernyataan yang ditanggapi menggunakan lima poin Skala Likert. 
Tabel 3.

Deskripsi Jawaban Responden terhadap Keunggulan Bersaing

\begin{tabular}{|c|c|c|c|c|c|c|c|c|c|}
\hline \multirow{3}{*}{ No } & \multirow{3}{*}{ Pernyataan } & \multirow{2}{*}{\multicolumn{5}{|c|}{$\begin{array}{l}\text { Proporsi Jawaban } \\
\text { Responden }\end{array}$}} & \multirow{3}{*}{ Jumlah } & \multirow{3}{*}{$\begin{array}{c}\text { Rata- } \\
\text { rata }\end{array}$} & \multirow{3}{*}{ Kriteria } \\
\hline & & & & & & & & & \\
\hline & & 1 & 2 & 3 & 4 & 5 & & & \\
\hline 1 & $\begin{array}{l}\text { Harga produk yang saya } \\
\text { tawarkan } \\
\text { bersaing dengan produk } \\
\text { endek tradisional lainnya. }\end{array}$ & 20 & 3 & 12 & 44 & 17 & 323 & 3.36 & $\begin{array}{l}\text { Cukup } \\
\text { Baik }\end{array}$ \\
\hline 2 & $\begin{array}{l}\text { Produk yang saya jual } \\
\text { berkualitas tinggi. }\end{array}$ & 15 & 0 & 19 & 49 & 13 & 333 & 3.47 & Baik \\
\hline 3 & $\begin{array}{l}\text { Saya selalu mengirimkan } \\
\text { barang ke pelanggan tepat } \\
\text { waktu. }\end{array}$ & 15 & 1 & 23 & 40 & 17 & 331 & 3.45 & Baik \\
\hline 4 & $\begin{array}{l}\text { Saya selalu berusaha } \\
\text { mengenalkan produk baru } \\
\text { lebih cepat dari pesaing. }\end{array}$ & 14 & 1 & 20 & 50 & 11 & 331 & 3.45 & Baik \\
\hline 5 & $\begin{array}{l}\text { Keuntungan dari usaha } \\
\text { penjualan kain endek saya } \\
\text { cukup stabil. }\end{array}$ & 13 & 3 & 24 & 42 & 14 & 329 & 3.43 & Baik \\
\hline \multicolumn{8}{|c|}{ Rata-rata } & 3,43 & Baik \\
\hline
\end{tabular}

Sumber: Data primer (data diolah), 2020

Berdasarkan Tabel 4. secara umum diperoleh hasil bahwa rata-rata skor variabel Orientasi Pasar berada pada kategori cukup baik. Terdapat tiga indikator dalam kategori cukup baik dan hanya 1 indikator yang berada pada kategori baik. Hal ini berarti bahwa sebagian responden masih belum mengoptimalkan strategi orientasi pasar untuk mengelola usahanya dalam hal orientasi pelanggan, rencana pemasaran untuk menanggapi kebutuhan pelanggan, dan strategi untuk mengungguli produk pesaing.

Variabel Orientasi Pasar yang memiliki rata-rata terendah adalah pernyataan "usaha yang saya kelola mengumpulkan informasi tentang kebutuhan pelanggan", diperoleh nilai rata-rata sebesar 3,26 yang masuk kriteria cukup, tetapi memiliki nilai rata-rata yang rendah dibandingkan dengan pernyataan yang lainnya ini berarti secara umum selama ini usaha yang responden kelola belum mengumpulkan informasi tentang kebutuhan pelanggan. Variabel Orientasi Pasar yang memiliki rata-rata tertinggi adalah pernyataan "saya tahu produk mana yang ditawarkan pesaing kepada pelanggan.", diperoleh nilai rata-rata sebesar 3,49 yang masuk kriteria baik, ini berarti secara umum responden tahu produk yang ditawarkan pesaing kepada pelanggan.

Variabel Strategi Diferensiasi pada penelitian ini merupakan variabel bebas. Variabel Strategi Diferensiasi yang disimbolkan dengan X2 serta diukur dengan menggunakan lima pernyataan yang ditanggapi menggunakan 5 poin Skala Likert.

Berdasarkan Tabel 5. secara umum diperoleh hasil bahwa rata-rata skor variabel Strategi Diferensiasi berada pada kategori baik. Hal ini berarti bahwa sebagian besar responden telah melakukan Strategi Diferensiasi dengan baik untuk mengelola usaha mereka. 
Tabel 4.

Deskripsi Jawaban Responden terhadap Orientasi Pasar

\begin{tabular}{|c|c|c|c|c|c|c|c|c|c|}
\hline \multirow[t]{2}{*}{ No } & \multirow[t]{2}{*}{ Pernyataan } & \multicolumn{5}{|c|}{$\begin{array}{l}\text { Proporsi Jawaban } \\
\text { Responden }\end{array}$} & \multirow[t]{2}{*}{ Jumlah } & \multirow{2}{*}{$\begin{array}{l}\text { Rata- } \\
\text { rata }\end{array}$} & \multirow[t]{2}{*}{ Kriteria } \\
\hline & & 1 & 2 & 3 & 4 & 5 & & & \\
\hline 1 & $\begin{array}{l}\text { Usaha yang saya kelola } \\
\text { mengumpulkan } \\
\text { informasi tentang } \\
\text { kebutuhan pelanggan. }\end{array}$ & 21 & 4 & 18 & 35 & 18 & 313 & 3.26 & $\begin{array}{c}\text { Cukup } \\
\text { Baik }\end{array}$ \\
\hline 2 & $\begin{array}{l}\text { Saya tahu produk mana } \\
\text { yang ditawarkan pesaing } \\
\text { kepada } \\
\text { pelanggan. }\end{array}$ & 14 & 2 & 21 & 41 & 18 & 335 & 3.49 & Baik \\
\hline 3 & $\begin{array}{lr}\text { Saya selalu } & \text { berusaha } \\
\text { membuat } & \text { rencana } \\
\text { pemasaran } & \text { berdasarkan } \\
\text { informasi } & \text { kebutuhan } \\
\text { pelanggan. } & \end{array}$ & 13 & 4 & 26 & 38 & 15 & 326 & 3.40 & $\begin{array}{c}\text { Cukup } \\
\text { Baik }\end{array}$ \\
\hline 4 & $\begin{array}{l}\text { Saya selalu memiliki } \\
\text { strategi untuk dapat } \\
\text { unggul berhadapan } \\
\text { dengan produk pesaing. }\end{array}$ & 9 & 6 & 35 & 31 & 15 & 325 & 3.39 & $\begin{array}{c}\text { Cukup } \\
\text { Baik }\end{array}$ \\
\hline & & ata-r & & & & & & 3,38 & $\begin{array}{l}\text { Cukup } \\
\text { Baik }\end{array}$ \\
\hline
\end{tabular}

Sumber: Data primer (data diolah), 2020

Variabel Strategi Diferensiasi yang memiliki rata-rata terendah adalah pernyataan "desain kain endek produksi saya dapat dengan mudah dikenali dibandingkan dengan produk pesaing", diperoleh nilai rata-rata sebesar 3,38 yang masuk kriteria cukup, tetapi memiliki nilai rata-rata yang rendah dibandingkan dengan pernyataan yang lainnya. Ini berarti secara umum desain kain endek diproduksi oleh responden belum dapat dengan mudah dikenali dibandingkan dengan produk pesaing. Variabel Strategi Diferensiasi yang memiliki rata-rata tertinggi adalah pernyataan "pelanggan mudah memesan produk yang saya jual lewat berbagai macam cara", diperoleh nilai rata-rata sebesar 3,53 yang masuk kriteria baik, ini berarti secara umum responden meyakini telah menjual produk mereka lewat berbagai macam cara yang memudahkan pelanggan mereka.

Variabel Inovasi Produk pada penelitian ini merupakan variabel bebas. Variabel Inovasi Produk yang disimbolkan dengan X3 serta diukur dengan menggunakan lima pernyataan yang ditanggapi menggunakan lima poin Skala Likert.

Berdasarkan Tabel 6. secara umum diperoleh hasil bahwa rata-rata skor variabel Inovasi Produk berada pada kategori cukup baik. Terdapat empat indikator dalam kategori cukup baik dan hanya satu indikator yang berada pada kategori baik. Hal ini berarti bahwa sebagian responden masih belum mengoptimalkan aneka strategi inovasi produk untuk mengelola usahanya. Fokus utama responden secara 
umum dan yang sudah baik dalam melakukakan inovasi produk adalah dengan mempertimbangkan produk yang paling laku di pasaran.

Tabel 5.

Deskripsi Jawaban Responden terhadap Strategi Diferensiasi

\begin{tabular}{|c|c|c|c|c|c|c|c|c|c|}
\hline \multirow[t]{2}{*}{ No } & \multirow[t]{2}{*}{ Pernyataan } & \multicolumn{5}{|c|}{$\begin{array}{l}\text { Proporsi Jawaban } \\
\text { Responden }\end{array}$} & \multirow[t]{2}{*}{ Jumlah } & \multirow{2}{*}{$\begin{array}{c}\text { Rata- } \\
\text { rata }\end{array}$} & \multirow[t]{2}{*}{ Kriteria } \\
\hline & & 1 & 2 & 3 & 4 & 5 & & & \\
\hline 1 & $\begin{array}{lrr}\text { Desain } & \text { kain } & \text { endek } \\
\text { produksi saya } & \text { dapat } \\
\text { dengan mudah } & \text { dikenali } \\
\text { dibandingkan } & \text { dengan } \\
\text { produk pesaing. } & \end{array}$ & 14 & 2 & 26 & 42 & 12 & 324 & 3.38 & $\begin{array}{l}\text { Cukup } \\
\text { Baik }\end{array}$ \\
\hline 2 & $\begin{array}{l}\text { Produk kain endek saya } \\
\text { sulit ditiru oleh pesaing. }\end{array}$ & 13 & 2 & 22 & 41 & 18 & 337 & 3.51 & Baik \\
\hline 3 & $\begin{array}{lr}\text { Harga produk yang saya } \\
\text { tawarkan } & \text { mampu } \\
\text { dijangkau } & \text { oleh } \\
\text { pelanggan. } & \end{array}$ & 14 & 0 & 22 & 49 & 11 & 331 & 3.45 & Baik \\
\hline 4 & $\begin{array}{l}\text { Pelanggan mudah } \\
\text { memesan produk yang } \\
\text { saya jual lewat berbagai } \\
\text { macam cara. }\end{array}$ & 13 & 1 & 22 & 42 & 18 & 339 & 3.53 & Baik \\
\hline 5 & $\begin{array}{lr}\text { Saya selalu } & \text { berusaha } \\
\text { memberikan } & \text { pelayanan } \\
\text { melebihi } & \text { harapan } \\
\text { pelanggan. } & \end{array}$ & 13 & 2 & 30 & 37 & 14 & 325 & 3.39 & $\begin{array}{l}\text { Cukup } \\
\text { Baik }\end{array}$ \\
\hline \multicolumn{8}{|c|}{ Rata-rata } & 3,45 & Baik \\
\hline
\end{tabular}

Sumber: Data primer (data diolah), 2020

Variabel Inovasi Produk yang memiliki rata-rata terendah adalah pernyataan "saya sudah mencoba menjual produk di luar negeri", diperoleh nilai rata-rata sebesar 3,29 yang masuk kriteria cukup, tetapi memiliki nilai rata-rata yang rendah dibandingkan dengan pernyataan yang lainnya ini berarti secara umum responden belum mencoba menjual produk di luar negeri. Variabel Inovasi Produk yang memiliki rata-rata tertinggi adalah pernyataan "saya membuat desain baru dengan mempertimbangkan produk saya yang paling laku di pasaran”, diperoleh nilai rata-rata sebesar 3,45 yang masuk kriteria baik, ini berarti secara umum responden membuat desain baru dengan mempertimbangkan produk mereka yang paling laku di pasaran.

Model analisis regresi linear berganda digunakan untuk mendapat koefisien regresi yang akan menentukan apakah hipotesis yang dibuat akan diterima atau ditolak. Hasil analisis ini mengacu pada hasil pengaruh variabel Orientasi Pasar (X1), variabel Strategi Diferensiasi (X2), dan variabel Inovasi Produk (X3) terhadap Keunggulan Bersaing (Y) pada Industri Endek Di Kabupaten Klungkung. Adapun hasil analisis regresi dengan program Statitical Package of Social Science (SPSS) versi 21.0 for Windows dapat dilihat pada Tabel 7. 
Tabel 6.

Deskripsi Jawaban Responden terhadap Inovasi Produk

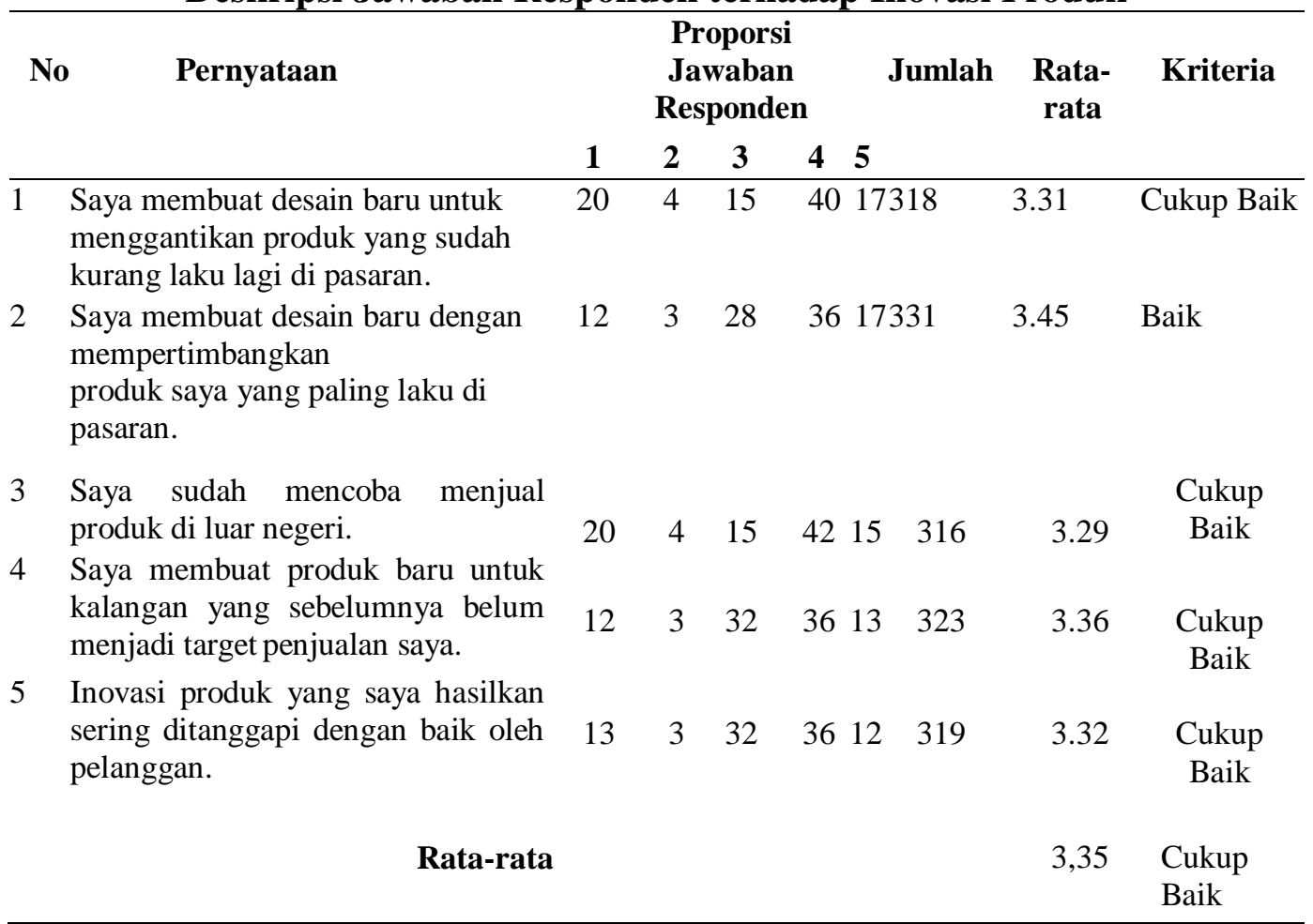

Sumber: Data primer (data diolah), 2020

Tabel 7.

Rangkuman Hasil Analisis Regresi Linear Berganda

\begin{tabular}{llclcc}
\hline Model & $\begin{array}{l}\text { Unstandardized } \\
\text { Coefficients } \\
\text { B }\end{array}$ & Std. Error & $\begin{array}{l}\text { Standardized } \\
\text { Coefficients } \\
\text { Beta }\end{array}$ & t hitung & Sig. \\
& 0.125 & 0.186 & & 0.671 & 0.504 \\
\hline Constant) & 0.529 & 0.099 & 0.507 & 5.330 & 0.000 \\
Orientasi Pasar & 0.163 & 0.082 & 0.162 & 2.002 & 0.048 \\
Strategi & 0.163 & 0.091 & 0.278 & 3.110 & 0.002 \\
$\begin{array}{l}\text { Diferensiasi } \\
\text { Inovasi Produk }\end{array}$ & 0.284 & & & &
\end{tabular}

Sumber: Data primer (data diolah), 2020 berikut.

Berdasarkan Tabel 7. dapat ditulis persamaan regresi linear berganda sebagai $\mathrm{Y}=0,125+0,529 \mathrm{X} 1+0,163 \mathrm{X} 2+0,284 \mathrm{X} 3$

Koefisien regresi X1 sebesar 0,529 memiliki arti orientasi pasar berpengaruh positif terhadap keunggulan bersaing, dengan kata lain semakin tinggi faktor orientasi pasar maka keunggulan bersaing meningkat. Koefisian regresi X2 sebesar 0,163 memiliki arti strategi diferensiasi berpengaruh positif terhadap keunggulan bersaing, dengan kata lain semakin tinggi faktor strategi diferensiasi maka keunggulan bersaing meningkat. Koefisian regresi X3 sebesar 0,284 memiliki arti 
inovasi produk berpengaruh positif terhadap keunggulan bersaing, dengan kata lain semakin tinggi faktor inovasi produk maka keunggulan bersaing meningkat

Tabel 8.

Analisis Determinasi

\begin{tabular}{ccccc}
\hline Model & R & R Square & $\begin{array}{l}\text { Adjusted } \boldsymbol{R} \\
\text { Square }\end{array}$ & $\begin{array}{l}\text { Std. Error of the } \\
\text { Estimate }\end{array}$ \\
\hline 1 & $0.890^{\mathrm{a}}$ & 0.793 & 0.786 & 0.54237 \\
\hline
\end{tabular}

Sumber: Data primer (data diolah), 2020

Berdasarkan hasil tersebut diketahui bahwa nilai R-Square 79,3 persen, yang berarti bahwa sebesar 79,3 persen Keunggulan Bersaing dipengaruhi oleh variabel Orientasi Pasar (X1), Strategi Diferensiasi (X2), dan Inovasi Produk (X3) dan sisanya sebesar 20,7 persen dipengaruhi oleh variabel lain yang tidak diteliti pada penelitian ini

Tabel 9.

Hasil Uji F

\begin{tabular}{|c|c|c|c|c|c|c|}
\hline Model & & $\begin{array}{l}\text { Sum of } \\
\text { Squares }\end{array}$ & DF & Mean Square & $\mathbf{F}$ & Sig. \\
\hline \multirow{3}{*}{1} & Regression & 103.603 & 3 & 34.534 & 117.397 & $0.000^{b}$ \\
\hline & Residual & 27.063 & 92 & 0.294 & & \\
\hline & Total & 130.666 & 95 & & & \\
\hline
\end{tabular}

Sumber: Data primer (data diolah), 2020

Berdasarkan hasil analisis, diketahui nilai signifikansi $\mathrm{F}$ adalah $0,000<0,05$, maka H0 ditolak. Hal ini berarti bahwa variabel Orientasi Pasar (X1), variabel Strategi Diferensiasi (X2), variabel Inovasi Produk (X3), secara simultan berpengaruh signifikan terhadap Keunggulan Bersaing (Y), atau model yang digunakan dalam penelitian layak dan dapat dipergunakan untuk analisis berikutnya.

Berdasarkan hasil analisis data didapat bahwa Orientasi Pasar berpengaruh positif terhadap Keunggulan Bersaing. Hal tersebut ditunjukan dengan nilai signifikansi sebesar 0,000 dengan nilai koefisien regresi sebesar 0,529 bernilai positif. Nilai signifikansi $0,000<0,05$ mengindikasikan bahwa $\mathrm{H} 1$ diterima. Hasil ini mempunyai arti bahwa Orientasi Pasar berpengaruh positif dan signifikan terhadap Keunggulan Bersaing. Hal ini berarti jika Orientasi Pasar semakin baik, maka Keunggulan Bersaing semakin meningkat, sebaliknya jika Orientasi Pasar semakin buruk maka Produktivitas kerja akan semakin buruk pula.

Orientasi pasar memiliki tiga komponen: orientasi pelanggan, orientasi pesaing dan koordinasi antar fungsi. Orientasi pelanggan dan orientasi pesaing adalah kegiatan yang selalu terlibat dalam memperoleh informasi tentang konsumen dan pesaing di pasar sasaran, sementara koordinasi antar fungsi didasarkan pada informasi pelanggan dan pesaing dan terdiri dari usaha bisnis yang terkoordinasi. Jika ketiga komponen ini diimplementasikan oleh perusahaan, maka perusahaan akan dapat menerapkan orientasi pasar dalam mencari berbagai 
informasi pasar sehingga dapat menjadi dasar bagi perusahaan untuk menentukan langkah selanjutnya.

Sebuah bisnis yang menerapkan orientasi pasar tentu akan mengetahui informasi tentang pembeli sehingga perusahaan dapat dengan mudah mendapatkan pelanggan atau pelanggan. Penerapan orientasi pasar ini juga akan berorientasi pada pesaing, dimana kegiatan ini merupakan kegiatan untuk mengetahui kelemahan atau kekurangan produk yang dihasilkan oleh pesaing, sehingga perusahaan dapat menghasilkan produk yang lebih baik daripada pesaing.

Hasil penelitian ini sesuai dengan penelitian yang dilakukan oleh Jayaningrum \& Sanawiri (2018) mengenai pengaruh orientasi pasar tehadap keunggulan bersaing kuliner kafe di Kota Malang menunjukkan bahwa orientasi pasar berpengaruh secara positif dan signifikan terhadap keunggulan bersaing. Perusahaan yang menerapkan orientasi pasar memiliki kelebihan dalam hal pengetahuan pelanggan dan kelebihan ini dapat dijadikan sebagai sumber untuk menciptakan produk yang sesuai dengan keinginan dan kebutuhan pelanggan. Penelitian yang dilakukan oleh Herman et al. (2018) menunjukkan bahwa orientasi pasar memiliki pengaruh yang positif terhadap keunggulan bersaing.

Berdasarkan hasil analisis data didapat bahwa Strategi Difrensiasi berpengaruh positif terhadap Keunggulan Bersaing. Hal tersebut ditunjukan dengan nilai signifikansi sebesar 0,048 dengan nilai koefisien regresi sebesar 0,163 bernilai positif. Nilai signifikansi $0,048<0,05$ mengindikasikan bahwa $\mathrm{H} 1$ diterima. Hasil ini mempunyai arti bahwa Strategi Difrensiasi berpengaruh positif dan signifikan terhadap Keunggulan Bersaing. Hal ini berarti jika Strategi Difrensiasi semakin baik, maka Keunggulan Bersaing semakin meningkat, sebaliknya jika Strategi Difrensiasi semakin buruk maka Produktivitas kerja akan semakin buruk pula

Keuntungan besar di balik strategi diferensiasi adalah memungkinkan perusahaan untuk mengisolasi diri sebagian dari persaingan kompetitif dalam industri. Ketika perusahaan menghasilkan produk yang sangat dicari dan berbeda, mereka tidak harus terlibat dalam perang harga yang merusak dengan pesaing mereka. Keuntungan lain di balik diferensiasi adalah bahwa pelanggan produk yang dibedakan kurang sensitif terhadap harga. Hal ini berarti bahwa, produsen dapat menaikan harga produknya tanpa harus terlalu khawatir kehilangan pelanggan.

Hasil penelitian ini sesuai dengan penelitian yang dilakukan oleh Hakim \& Faizah (2018) yang menemukan bahwa diferensiasi mempunyai pengaruh positif signifikan terhadap keunggulan bersaing. Strategi diferensiasi didasarkan pada pelayanan atau bentuk dengan sesuatu yang berbeda atau unik, yang membuat produk atau jasa perusahaan berbeda dari para pesaingnya. Menurut hasil pembahasan oleh Setyowati \& Fadah (2018) mengatakan strategi diferensiasi berpengaruh pada keunggulan bersaing, karena dengan bisa menciptakan perbedaan perusahaan yang tidak dimiliki oleh perusahaan yang lain dia akan bisa menghasilkan keunggulan. Penelitian yang dilakukan oleh Job \& Nyongesa (2016) menunjukkan bahwa strategi difrensiasi produk berpengaruh secara positif terhadap keunggulan bersaing. Diferensiasi produk mencerminkan tekanan kompetitif yang diberikan oleh produsen dan pelanggan. Secara tidak langsung, meningkatkan fokus pelanggan dapat membantu mengidentifikasi kesenjangan pasar dan mengungkapkan peluang pasar baru 
Berdasarkan pengolahan data SPSS dihasilkan tingkat signifikansi 0,002 < 0,05. Berdasarkan nilai pengujian tersebut, dapat dilihat dengan statistik bahwa uji jatuh pada penolakan $\mathrm{H}_{0}$ ditolak dan $\mathrm{H}_{1}$ diterima untuk hipotesis ketiga. Hal tersebut menyatakan penerimaan hipotesis yang bahwa terdapat pengaruh positif dan signifikan antara terhadap Keunggulan Bersaing. Koefisien regresi variabel X3 adalah positif 0,284, artinya apabila Inovasi Produk meningkat sedangkan Orientasi Pasar dan Strategi Diferensiasi tetap, maka Keunggulan Bersaing akan meningkat sebesar 0,284.Produk yang sudah lama dipasarkan dan adanya produk dengan karakteristik sejenis dari produsen lain akan membuat produk mencapai titik jenuh dipasaran, diperlukan sebuah inovasi untuk mengganti produk lama tersebut. Penggantian ini dapat berupa produk pengganti yang secara total baru atau dengan perkembangan produk lama yang lebih modern dan up to date, sehingga dapat terus meningkatkan keinginan konsumen dalam keputusan pembelian produk tersebut. Inovasi juga dapat berupa membuat produk dengan fungsi baru atau disesuaikan dengan target pasar baru. Hal ini akan dapat menarik konsumen potensial yang sebelumnya tidak terjangkau untuk menjadi pelanggan baru dari produk.

Hasil penelitian ini sesuai dengan penelitian yang dilakukan oleh Dalimunthe (2017) menunjukkan bahwa inovasi produk memiliki pengaruh positif terhadap keunggulan bersaing. Penelitian Kurniasari \& Utama (2018) pada UKM kerajinan enceng gondok menunjukkan bahwa inovasi produk secara individual berpengaruh positif dan signifikan terhadap keunggulan bersaing. Perusahaan dapat melakukan berbagai inovasi dengan membuat berbagai macam desain produk, dan menambah nilai guna suatu barang.

Implkasi teoretis dari hasil penelitian ini memberikan bukti pada pengembangan ilmu perilaku konsumen dan pemasaran khususnya mengenai Orientasi Pasar, Strategi Diferensiasi, Inovasi Produk dan Keunggulan Bersaing. Hasil penelitian ini memberi dukungan empiris dan dapat dinyatakan memperkuat hasil-hasil studi terdahulu. Hasil penelitian ini secara praktis dapat menjadi salah satu acuan bagi peneliti lainnnya yang ingin meneliti mengenai Orientasi Pasar, Strategi Diferensiasi, Inovasi Produk dan Keunggulan Bersaing. Secara teoritis penelitian ini juga memberikan pemahaman bahwa Orientasi Pasar, Strategi Diferensiasi dan Inovasi Produk secara nyata dapat meningkatkan Keunggulan Bersaing, dengan meningkatkan Orientasi Pasar, Strategi Diferensiasi dan Inovasi Produk maka Keunggulan Bersaing akan mengalami peningkatan.

Implementasi praktis dari penelitian ini adalah perlu dilakukan upaya yang lebih baik dalam hal melakukan tindakan untuk orientasi pelanggan, rencana pemasaran untuk menanggapi kebutuhan pelanggan, serta strategi untuk mengungguli produk pesaing. Secara umum pengusaha endek di kabupataen Klungkung baru sebatas melakukan tindakan orientasi pesaing. Tindakan yang lebih baik juga diperlukan untuk meningkatkan inovasi produk. Selama ini inovasi produk yang dilakukan hanya sebatas melakukan inovasi berdasarkan produk yang paling laku di pasaran, hal ini menutup peluang untuk melakukan perluasan pangsa pasar untuk semakin memperkuat keunggulan bersaing. Masih banyak aspek inovasi produk yang perlu ditingkatkan, seperti dengan cara menjual produk ke luar negeri, memperluas target pasar, mengganti produk yang kurang laku, serta menggali pendapat konsumen mengenai inovasi yang telah dilakukan. 
Beberapa keterbatasan penelitian yang dapat ditarik pada penelitian ini adalah faktor-faktor yang memepengaruhi keunggulan bersaing hanya dikonstruksi dari tiga variabel yaitu orientasi pasar, strategi diferensiasi, dan inovasi produk sedangkan masih terdapat faktor lain yang berpeluang memiliki andil dalam mempengaruhi keunggulan bersaing. Penelitian ini hanya dilakukan dalam periode waktu tertentu, sedangkan lingkungan setiap saat dapat berubah, sehingga penelitian ini penting untuk dilakukan kembali di masa mendatang.

\section{SIMPULAN}

Terdapat pengaruh positif dan signifikan secara parsial antara Orientasi Pasar terhadap Keunggulan Bersaing Pada Industri Endek di Kabupaten Klungkung Hal ini berarti semakin membuat Orientasi Pasar, maka semakin meningkat Keunggulan Bersaing. Terdapat pengaruh positif dan signifikan secara parsial antara Strategi Diferensiasi terhadap Keunggulan Bersaing Pada Industri Endek di Kabupaten Klungkung. Hal ini berarti semakin tingginya Strategi Diferensiasi, maka meningkatkan Keunggulan Bersaing. Terdapat pengaruh positif dan signifikan secara parsial antara Inovasi Produk terhadap Keunggulan Bersaing Pada Industri Endek di Kabupaten Klungkung. Hal ini berarti semakin tingginya Inovasi Produk, maka meningkatkan Keunggulan Bersaing.

Berdasarkan hasil kuisioner diperoleh bahwa untuk variabel orientasi pasar nilai rata-ratanya masih ada pada kategori cukup baik, sehingga sangat perlu ditingkatkan mengingat dari hasil analisis diperoleh bahwa orientasi pasar adalah variabel yang paling berpengaruh diantara dua variabel lainnya terhadap keunggulan bersaing. Pengusaha endek perlu meningkatkan orientasi pasar dengan cara mengumpulkan informasi tentang kebutuhan pelanggan, membuat rencana pemasaran berdasarkan kebutuhan pelanggan, dan mengimplementasikan strategi tersebut. Berdasarkan hasil kuisioner diperoleh bahwa untuk variabel strategi diferensiasi, aspek desain yang mewakili indikator diferensiasi produk memperoleh nilai paling rendah. Hal ini berarti bahwa, pengusaha endek perlu memperhatikan dan mendesain produknya agar lebih memiliki pembeda dan keunikan dari pesaingnya. Berdasarkan hasil kuisioner diperoleh bahwa untuk variabel inovasiproduk memperoleh nilai rata-rata terendah dibandingkan variabel lainnya. Perlu dilakukan usaha peningkatan inovasi produk dari segi efektivitas inovasi dan kinerja inovasi. Hal ini dilakukan dengan cara membuat desain baru untuk menggantikan produk lama yang kurang laku, menjual produk ke luar negeri, membuat produk untuk target pasar baru, serta meningkatkan kepuasan pelanggan atas inovasi yang dilakukan. Peneliti selanjutnya diharapkan memperluas cakupan penelitian dengan menggunakan atau menambah variabel lain di luar penelitian ini yang dapat mempengaruhi keunggulan bersaing seperti strategi kepemimpinan biaya rendah, strategi fokus, dan adaptabilitas terhadap lingkungan.

\section{REFERENSI}

Almaidah, S., \& Wagiyem. (2016). Analisis Pengaruh Kompetensi Kewirausahaan Terhadap Keberhasilan Usaha Dengan Lingkungan Internal Dan Eksternal 
Sebagai Variabel Moderator (Studi Pada Usaha Mikro Kecil Menengah Di Wilayah Surakarta). Buletin Ekonomi, 14(2), 193-208.

Dalimunthe, M. B. (2017). Keunggulan Bersaing Melalui Orientasi Pasar dan Inovasi produk. Jurnal Konsep Bisnis Dan Manajemen, 3(1), 18-31.

Doyle, J. D., \& Armenakyan, A. (2016). Value-creating mechanisms within the market orientation-performance relationship: A meta-analysis. Journal of Strategic Marketing, 22(3), 193-205.

Gault, F. (2018). Defining and Measuring Innovation in All Sectors of The Economy. Research Policy, 47(3), 617-622. https://doi.org/https://doi.org/10.1016/j.respol.2018.01.007

Gunarathne, D. P. U. (2015). Measurement Model of the Market Orientation: New Theoretical Framework NEWMKTOR Model. International Journal of Management and Commerce Innovations, 3(1), 255-263.

Hakim, M. A., \& Faizah, N. (2018). Analisis Strategi Differensiasi Citra Perusahaan dalam Pemasaran Sebagai Upaya Untuk Menciptakan Keunggulan Bersaing ( Studi Pada PT. Ar Tour dan Travel). Jurnal Bisnis Dan Manajemen Islam, 5(2), 383-406.

Hardjono, \& Utari, R. A. (2016). Pengaruh Strategi Diversifikasi dan Diferensiasi Produk terhadap Loyalitas Konsumen pada Kedai Pissbroo di Kabupaten Situbondo. Jurnal Administrasi Bisnis (JAB), 1(1), 1-16.

Herman, H., Hady, H., \& Arafah, W. (2018). The Influence of Market Orientation and Product Innovation on the Competitive Advantage and Its Implication toward Small and Medium Enterprises (UKM) Performance. International Journal of Science and Engineering Invention, 04(19-21), 8-21. https://doi.org/10.23958/ijsei/vol04-i08/02

Hosseini, A. S., Soltani, S., \& Mehdizadeh, M. (2018). Competitive advantage and its impact on new product development strategy (Case study: Toos Nirro technical firm). Journal of Open Innovation: Technology, Market, and Complexity, 4(17), 1-12. https://doi.org/10.3390/joitmc4020003

Jayaningrum, E., \& Sanawiri, B. (2018). Pengaruh Orientasi Pasar, Inovasi, Orientasi Kewirausahaan Terhadap Keunggulan Bersaing dan Kinerja Pemasaran. Jurnal Administrasi Bisnis (JAB), 54(1), 149-158.

Job, M., \& Nyongesa, M. B. (2016). Product Differentiation Strategy for Competitive Advantage in Kenya Cooperative Creameries. Africa Internation Al Journal of Management Education and Gov Ernance (AIJMEG), 1(1), 113. 
Julian, C. C., Mohamad, O., Ahmed, Z. U., \& Sefnedi, S. (2015). The market orientation-performance relationship: The empirical link in export ventures. Thunderbird International Business Review, 56(1), 1-15.

Kurniasari, R., \& Utama, A. (2018). The Effect of Product Innovation, Product Creativity, and Product Quality on Competitive Advantage (a Case Study of Handicraft Enceng Gondok “Akar”). Research Gate, 3(1), 467-477.

Love, L. G., \& Mcgee, J. E. (2015). Distinctive Competencies and Competitive Advantage : A Study- of Small Independent Retailers. Research Gate, 1(1), $1-15$.

Nasir, A. (2019). Pengaruh Inovasi Produk Terhadap Kinerja Pemasaran Industri Mebel Di Kabupaten Pasuruan. Jurnal Ilmu Manajemen Dan Akuntansi, 5(1), 20-25. https://doi.org/https://doi.org/10.33366/ref.v6i2.528

Pattipeilohy, V. R. (2018). Inovasi Produk dan Keunggulan Bersaing: Pengaruhnya terhadap Kinerja Pemasaran (Studi pada Usaha Nasi Kuning di Kelurahan Batu Meja Kota Ambon). Jurnal Maneksi, 7(1), 26-38. https://doi.org/10.31959/jm.v7i1.78

Sachitra, V. (2016). Review of Competitive Advantage Measurements: Reference on Agribusiness Sector. Journal of Scientific Research Dan Reports, 12(6), $1-11$.

Satyarini, R. (2016). Strategi Diferensiasi sebagai Alat untuk Memenangkan Persaingan pada Industri Kreatif di Bandung. Strategi Diferensiasi Sebagai Alat Untuk Memenangkan Persaingan Pada Industri Kreatif di Bandung. Bina Ekonomi, 20(1), 47-56. https://doi.org/https://doi.org/10.26593/be.v20i1.1905.47-56

Setyowati, T., \& Fadah, I. (2018). Differentiation Competitive Strategy in Winning Smes Advantage at Creative Industry in Jember. International Journal of Scientific and Technology Research, 7(2), 165-169.

Sigalas, C., \& Pekka Economou, V. (2017). Revisiting the concept of competitive advantage. Journal of Strategy and Management., 6(1), 1-37.

Sukarmen, P., Sularso, A., \& Wulandari, D. (2015). Analisis Pengaruh Inovasi Produk Terhadap Kepuasan Konsumen Dengan Keunggulan Bersaing Sebagai Variabel Intervening Pada Produk Gula Pasir Sebelas (Gupalas) Pabrik Gula Semboro Ptp Nusantara XI (Persero). Jurnal Ekonomi Akuntansi Dan Manajemen, 12(1), 64-79.

Supriyanto, A., Sukrina, H. R., \& Abidin, M. Z. (2017). Pengaruh Orientasi Pasar Dan Inovasi Produk Terhadap Keunggulan Bersaing (Studi pada UMKM 
Kopiah Haji di Kabupaten Hulu Sungai Tengah). AIMI, 1(1), 26-33.

Varadarajan, R. (2017). Research on market orientation: Some lessons shared and issues discussed in a doctoral seminar. AMS Review, 7(5), 26-35.

Zainul, M., Astuti, ndang S., Arifin, Z., \& Utami, H. N. (2016). The Effect of Market Orientation toward Organizational Learning, Innovation, Competitive Advantage, and Corporate Performance. Journal of Administrative Sciences and Policy Studies, 4(1), 1-19. https://doi.org/10.15640/jasps.v4n1a1

Zaricha, F. (2018). The Influence of Marketing Knowledge, Market Orientation and Marketing Capabilities Towards Marketing Performance in UMKM. Research Gate, 1(1), 1-30. 